\title{
Eksodus dari Bumi Hangus: Peristiwa Keluarnya Penduduk Dari Timor Timur Pasca Jajak Pendapat 1999
}

\author{
Jerwin, M. Rasyid Ridha, Ahmadin \\ Pendidikan Sejarah FIS UNM \\ jerwinunm@gmail.com
}

\begin{abstract}
Abstrak
Karya sederhana ini berupaya menjelaskan peristiwa keluarnya penduduk Timor Timur menuju ke Kabupaten Pangkep, karena terjadinya kerusuhan pasca pengumuman hasil Jajak Pendapat di daerah tersebut. Situasi menjadi mencekam dan menimbulkan rasa tidak aman dikalangan penduduk Timor Timur. Termasuk para pendatang, dari berbagai daerah Indonesia seperti Kabupaten Pangkep. Orang-orang Pangkep yang telah lama menetap di Timor Timur, pada umumnya sudah memiliki beberapa aset berharga. Seperti tanah, rumah, ruko, dan kendaraan. Namun sayangnya, aset-aset mereka ditinggal begitu saja, sebelum sempat dijual. Masalah aset para pendatang inilah yang kemudian dituntut untuk segera diselesaikan. Kajian mengenai Eksodus Timor Timur yang ada di Kabupaten Pangkep menjadi menarik karena kedatangan para pendatang di Timor Timur serta kepulangan mereka pasca jajak pendapat belum dikaji secara spesifik. Terutama yang berasal dari Sulawesi Selatan, khususnya Kabupaten Pangkep. Penelitian ini adalah penelitian kualitatif dengan pendekatan penelitian historis (Historical Research), yang terdiri atas beberapa tahapan yakni: (1) Heuristik, dengan melakukan wawancara terhadap beberapa warga Eksodus Timor Timur seperti Hasan, Salma, Muhris, dll. Mengumpulkan arsip di Dinas Sosial Kabupaten Pangkep, data-data yang dimiliki oleh Komite Nasional Korban Politik Timor Timur Kabupaten Pangkep, dan surat kabar terbitan 5 November 2016 dari Harian Fajar. Selain itu juga digunakan buku-buku yang terkait dengan Timor Timur, kependudukan dan kajian kemasyarakatan (Sosiologi/Antropologi). (2) Kritik atau proses verifikasi keaslian sumber sejarah. (3) Interpretasi atau penafsiran sumber sejarah, dan (4) Historiografi, yakni tahap penulisan sejarah.
\end{abstract}

Kata Kunci: Eksodus, Pangkep, Timor Timor.

\begin{abstract}
This paper is about to explain the incident of the East Timorese who moved to Pangkep District, due to the riots after the announcement of the results of the Popular Consultation in the area. The situation became tense and caused insecurity among the people of East Timor. Including the migrants, from various regions of Indonesia such as Pangkep District. Pangkep people who have stay for a long time in East Timor, in general already have some valuable assets. Such as land, house, shop, and vehicle. But unfortunately, their assets were left behind, before being sold. The problem of the assets of the newcomers is then required to be resolved immediately. The study of the East Timor Exodus in Pangkep District is interesting because the arrival of migrants in East Timor and their return after the referendum has not been specifically studied. Especially coming from South Sulawesi, especially Pangkep regency. This research is a qualitative research with Historical Research approach, which consist of several stages: (1) Heuristic, by interviewing some East Timor Exodus people like Hasan, Salma, Muhris, etc. Collecting records at the Pangkep District Social Service, data held by the National Committee for East Timor Police Victims of Pangkep District, and in the November 5, 2016,
\end{abstract}


issue of the Daily Fajar newspaper. It also used books related to East Timor, population and societal studies (Sociology / Anthropology). (2) Criticism or verification process of authenticity of historical sources. (3) Interpretation or interpretation of historical sources, and (4) Historiography, is the stage of historical writing.

Keywords: Exodus, Pangkep, Timor Timur.

\section{A. Pendahuluan}

Semenjak resmi menjadi bagian dari Indonesia, gelombang pendatang mulai berdatangan ke Timor Timur, baik dari pulau Jawa maupun luar Jawa termasuk dari Sulawesi. Hal ini menyebabkan terjadinya pertumbuhan penduduk yang tinggi antara 1980-1990. (Tirtosudarmo, 1996).

Kedatangan para pendatang ke Timor Timur dilandasi oleh beberapa alasan, terutama didasari alasan-alasan ekonomis, dan bagi mereka yang menduduki jabatan di pemerintahan didasari oleh alasan kedinasan. Timor Timur telah menjadi tempat yang terbuka bagi para pendatang yang ingin mengembangkan berbagai usaha perekonomian dalam skala kecil. Gejala ini dapat dilihat antara lain dengan banyaknya pendatang dari daerah Sulawesi Selatan, yang banyak bekerja dalam bidang perdagangan. (Tirtosudarmo, 1996). Kabupaten Pangkep adalah salah satu Kabupaten di Sulawesi Selatan, yang turut andil dalam bidang perdagangan di Timor Timur. Kedatangan mereka di daerah ini pada umumnya karena adanya keinginan untuk memperbaiki taraf perekonomian.

Alasan ekonomi semacam ini diungkapkan oleh seorang narasumber bernama Hasan yang merupakan orang asli Pangkep dan saat ini menjabat sebagai ketua KOKPIT (Komite Nasional Korban Politik Timor Timur) provinsi Sulawesi Selatan.

"Karena disinikan pada waktu itu, cari pekerjaan susah yah makanya kita inikan orang Bugis-Makassar banyak merantau, termasuk ada yang merantau ke Timor Timur.” (Hasan, 2017)
Demikianlah jawaban narasumber ketika ditanya mengenai alasannya kenapa harus ke Timor Timur. Susahnya mencari pekerjaan di kampung halaman menyebabkan orang-orang Pangkep berusaha untuk mencari peluang kerja ke tempat lain yang menurut mereka bisa memperbaiki keadaan perekonomian. Lebih lanjut Hasan mengungkapkan bahwa orang-orang Pangkep yang datang ke Timor Timur pada umumnya untuk berdagang, mulai dari menjual ikan, pakaian hingga distributor sembako seperti dirinya.

Selain karena faktor kurangnya lapangan kerja, kepindahan penduduk ini juga karena adanya tugas negara bagi Pegawai Negeri Sipil (PNS) yang ditempatkan di Timor Timur. Seperti yang diceritakan oleh seorang narasumber bernama Salma

"Orang tua dulu disana bekerja sebagai PNS. Bapak berangkat duluan, baru saya sama Ibu menyusul kesana, pake kapal”. (Salma, 2017)

Salma ketika berangkat ke Timor Timur masih duduk dibangku kelas dua sekolah dasar, kemudian melanjutkan sekolahnya di Timor Timur hingga tamat SD, dan kembali ke Kabupaten Pangkep untuk lanjut di jenjang Sekolah Menengah Pertama (SMP) dan setelah tamat kembali lagi ke Timor Timur melanjutkan pendidikan di jenjang Sekolah Menengah Atas (SMA). Senada yang diungkapkan oleh Hasan, narasumber berumur 38 tahun ini juga mengungkapkan bahwa pada umumnya orang Pangkep yang datang ke Timor Timur bertujuan untuk berdagang.

Perjalanan sejarah pada akhirnya mengantarkan Timor Timur pada akhir 
cerita sebagai provinsi termuda Indonesia. Pada 30 Agustus tahun 1999 diadakan jajak pendapat secara serentak di Timor Timur untuk menawarkan dua opsi yaitu otonomi khusus dengan tetap menjadi bagian dari Indonesia atau merdeka. Hasil dari jajak pendapat ini diumumkan pada 4 September 1999 dan hasilnya 21,5\% memilih otonomi khusus dan 78,5\% memilih untuk merdeka. Pasca jajak pendapat terjadi kerusuhan besar-besaran di Timor Timur yang menyebabkan terjadinya gelombang pengungsian. Penduduk mengungsi secara masif ke bukit, hutan, dan adapula yang lari ke Timor Barat. (Hadi \& dkk, 2007). Begitupun dengan para pendatang yang berasal dari Kabupaten Pangkep, memilih untuk kembali ke kampung halaman mereka akibat kerusuhan pasca Jajak Pendapat tersebut.

Kajian mengenai Timor Timur telah banyak diangkat oleh penulis/peneliti dalam berbagai macam bentuk karya tulis. Misalnya oleh Tyas Suartika dengan judul Korban Jajak Pendapat di Timor Timur, 1999, yang terbit pada sebuah jurnal bertajuk Avatara, e-Journal Pendidikan Sejarah milik UNESA. Fokus utama penelitiannya adalah mereka yang menjadi korban dari konflik di Timor Timur pasca Jajak Pendapat. Baik itu dari kubu prokemerdekaan maupun kubu pro-integrasi yang mengalami luka-luka, mengungsi, hingga yang meninggal dunia. Perbedaan kajian Tyas Suartika dengan penelitian ini adalah pada fokus utama kajiannya. Tyas Suartika dalam penelitiannya membahas secara umum korban Jajak Pendapat di Timor Timur, baik dari pihak prokemerdekaan dan pro-integrasi. Tanpa secara spesifik membahas mengenai nasib para pendatang yang ada di Timor Timur, serta peristiwa keluarnya penduduk dari Timor Timur pasca Jajak Pendapat. Sementara dalam penelitian ini, fokus utama kajiannya adalah mengisahkan salah satu bagian peristiwa sejarah Timor Timur yang dialami oleh para pendatang asal
Kabupaten Pangkep dan penduduk Timor Timur yang memilih untuk meninggalkan daerahnya menuju ke Kabupaten Pangkep pasca pengumuman Jajak Pendapat yang berakhir dengan kerusuhan.

Adapula karya seorang wartawati Kompas bernama C.M. Rien Kuntari dengan judul Timor Timur Satu Menit Terakhir: Catatatn Seorang Wartawan. Tulisan ini berisi pengalaman penulisnya selama bertugas sebagai wartawati di Timor Timur. Fokus utama tulisannya menceritakan berbagai macam dinamika yang terjadi menjelang berpisahnya Timor Timur dari pangkuan Ibu Pertiwi. Tetapi dibagian awal tulisannya juga digambarkan bagaimana latar belakang bergabungnya daerah tersebut menjadi provinsi ke-27 Indonesia. Jelas bahwa dalam tulisan C.M. Rien Kuntari tidak membahas secara khusus kedatangan serta kepulangan para pendatang di Timor Timur, pun peristiwa mengungsinya penduduk dari daerah tersebut karena terjadinya kerusuhan belum dikaji. Adapun dalam penelitian ini, akan berusaha untuk menguraikan apa yang belum disajikan dalam tulisan C.M. Rien Kuntari tersebut.

Peristiwa keluarnya penduduk dari Timor Timur secara besar-besaran merupakan salah satu fenomena yang banyak menyita perhatian dunia menjelang pergantian milenium baru. Fenomena semacam ini dikenal dengan istilah Eksodus, sehingga mereka para penduduk Timor Timur baik penduduk asli ataupun pendatang yang saat ini berada dalam wilayah NKRI dikenal dengan sebutan "Warga Eksodus Timor Timur".

Pada kasus Timor Timur fenomena Eksodus yang terjadi disebabkan karena adanya kerusuhan pasca Jajak Pendapat. Kerusuhan ini seolah ingin membumi hanguskan Timor Timur dengan melakukan pengrusakan dan pembakaran terhadap rumah penduduk, tempat ibadah, gedung pemerintah, ataupun fasilitas publik lainnya. Aksi bumi hangus semacam ini dilakukan oleh para milisi yang kecewa 
dengan hasil Jajak Pendapat. (Dalam Kamus Besar Bahasa Indonesia "Membumi Hanguskan" diartikan memusnahkan sama sekali seperti barang, bangunan, dan gedung penting yang mungkin dipakai oleh musuh, dengan pembakaran) (Departemen Pendidikan Nasional, 2003)

Pada penelitian ini fenomena Eksodus tersebut akan di fokuskan ke Kabupaten Pangkep, dalam sebuah judul Eksodus Dari Bumi Hangus (Peristiwa Keluarnya Penduduk Dari Timor Timur Pasca Jajak Pendapat 1999).

\section{B. Metode Penelitian}

Penelitian ini adalah penelitian sejarah dengan menggunakan metode yang sesuai dengan kaidah keilmuan sejarah, sebagaimana berikut.

\section{Heuristik}

Tahap pertama dalam penelitian sejarah berupa pengumpulan sumbersumber yang dikenal dengan istilah Heuristik.

Terdapat beberapa klasifikasi sumber sejarah, namun pada umumnya dikenal dengan dua pembagian. Pertama, sumber primer yakni sumber sejarah yang direkam dan dilaporkan oleh para saksi mata (eyewitness). Kedua, sumber sekunder disampaikan bukan oleh orang yang menyaksikan atau partisipan suatu peristiwa sejarah. (Daliman, 2015)

Penelusuran sumber yang dilakukan untuk penelitian ini, dilakukan dengan berberapa cara. Diantaranya mengumpulkan sumber primer dengan melakukan wawancara terhadap beberapa orang yang pernah tinggal di Timor Timur. Wawancara ini dilaksanakan di Kabupaten Pangkep terhadap empat orang narasumber yaitu; Salma, Muhris, H. Sanusi, Abdul Gani, dan Anwar Sadat. Selain di Kabupaten Pangkep, wawancara juga dilakukan di Kota Makassar terhadap seorang narasumber bernama Hasan.

Selain melalui wawancara data primer juga diperoleh dari arsip yang tersimpan di
Dinas Sosial Kabupaten Pangkep, dan surat kabar terbitan 5 November 2016 dari Harian Fajar.

Sementara itu, sumber sekunder yang digunakan dalam penelitian ini diperoleh dengan mengumpulkan buku-buku yang terkait dengan Timor Timur, kependudukan serta buku dengan tema kajian kemasyarakatan (Sosiologi/ Antropologi).

Buku yang menjadi rujukan dalam penelitian ini diperoleh baik dari penelusuran di perpustakaan pusat Universitas Negeri Makassar, perpustakaan Jurusan Pendidikan Sejarah FIS UNM, dan perpustakaan wilayah Sulawesi Selatan, serta ada pula yang merupakan koleksi pribadi penulis.

\section{Kritik}

Tahap kedua dalam penelitian sejarah adalah kritik sumber. Hasil yang ingin dicapai pada tahap ini adalah didapatnya sumber sejarah yang benar-benar memberikan fakta guna merekonstruksi masa lalu. Terdapat dua aspek yang harus diverifikasi yaitu Otentisitas atau keaslian sumber (kritik eksternal), dan kredibilitas atau tingkat kebenaran informasi dari sumber sejarah (kritik internal). (Hamid \& Madjid, 2014).

Tahap kritik terhadap sumber-sumber yang digunakan dalam penelitian ini umumnya dilakukan secara mendalam terhadap keterangan-keterangan yang dituturkan oleh narasumber, dengan cara melakukan komparasi antara narasumber yang satu dengan lainnya, atau komparasi antara pengakuan narasumber dengan sumber tertulis yang ada. Hal ini dilakukan untuk meminimalisir tingkat subjektifitas dari narasumber.

Selain itu kritik internal juga dilakukan pada berita yang dimuat oleh Harian Fajar terbitan 5 November 2016. Pada koran tersebut tertulis jumlah Kepala Keluarga yang berstatus Eksodus Timor Timur di Kabupaten Pangkep sebanyak 280 KK. Namun setelah dikomparasi dengan data base yang dimiliki oleh Komite Nasional 
Korban Politik Timor Timur jumlahnya adalah $286 \quad(285$ KK berdomisili di Pangkep, sementera satu KK berdomisili di luar Kabupaten Pangkep tetapi tercatat sebagai penerima di daerah ini). Hal semacam ini, dimungkinkan jika yang disebutkan oleh narasumber adalah 280-an tetapi yang tercatat oleh wartawan justru hanya angka $280 \mathrm{KK}$.

\section{Interpretasi}

Pada tahap ketiga peneliti harus menafsirkan data-data yang telah diperoleh. Proses menafsirkan memerlukan ketelitian dari seorang penulis untuk memilah data mana yang penting untuk tema penelitian dan data mana yang tidak berkaitan dengan penelitian.

Tidak jarang pada tahap ini ditemukan subjektivitas dalam penulisan sejarah karena adanya perbedaan pandangan, untuk menghindari subjektivitas tersebut maka penulis akan menggunakan pendekatan-pendekatan tertentu dalam menafsirkan. (Sjamsuddin, 2016).

Pada penelitian ini sumber-sumber sejarah yang telah lulus tahap kritik/verifikasi kemudian ditafsirkan sebelum diramu menjadi sebuah kisah sejarah. Proses penafsiran dilakukan terhadap sumber primer dari keterangan narasumber dan arsip dari Dinas Sosial Kabupaten Pangkep serta surat kabar dari Harian Fajar terbitan 5 November 2016. Penafsiran juga dilakukan terhadap sumber sekunder berupa buku yang terkait dengan Timor Timur, buku bertema demografi atau kependudukan dan buku bertema kajian kemasyarakatan (Sosiologi dan Antropologi). Hal ini dilakukan guna menemukan benang merah dari masalah yang ingin dikaji yakni Peristiwa Eksodus dari Timor Timur menuju Kabupaten Pangkep.

\section{Historiografi}

Pada tahap ini, data-data yang telah diseleksi oleh peneliti kemudian dituliskan dalam bentuk kisah sejarah. Historiografi merupakan puncak dari segala-galanya dalam metode penelitian sejarah. Sejarawan pada fase ini mencoba menangkap dan memahami histoire realite atau sejarah sebagaimana terjadinya. (Hamid \& Madjid, 2014).

Sumber-sumber sejarah yang telah ditafsirkan, baik primer maupun sekunder, pada tahap ini dirangkai sedemikian rupa untuk menyajikan sebuah kisah sejarah mengenai Timor Timur yang dialami oleh mereka yang "terbuang” dari bekas provinsi ke-27 Indonesia itu.

\section{Tinjauan Penelitian}

Kabupaten Pangkajene dan Kepulauan atau biasa disingkat dengan Kabupaten Pangkep, adalah daerah yang berada di sebelah barat Provinsi Sulawesi Selatan. Pada bagian ini akan diuraikan beberapa gambaran umum mengenai Kabupaten Pangkep untuk memahami karakteristik daerah tersebut sebagai lokasi penelitian. Data-data yang akan diuraikan pada bagian ini diperoleh dari arsip Badan Pusat Statistik tahun 1999 dan tahun 2016, serta data Dinas Kependudukan dan Catatan Sipil Kabupaten Pangkep tahun 2016.

Kabupaten Pangkep pada kurun waktu tahun 1999 hingga tahun 2016 tentu mengalami dinamika. Selama 17 tahun tersebut di daerah ini telah terjadi perubahan baik dalam hal wilayah administratif maupun kependudukan serta beberapa aspek lainnya sebagaimana yang akan diuraikan berikut ini.

\section{Letak Geografis}

Kabupaten Pangkajene dan Kepulauan terletak antara $110^{\circ} \mathrm{BT}$ sampai dengan $113^{\circ}$ BT dan $4.40^{\circ} \mathrm{LS}$ sampai dengan $8.00^{\circ} \mathrm{LS}$ atau terletak di pantai barat Sulawesi Selatan. Jarak Kabupaten Pangkep dari Ibu Kota Provinsi yakni Kota Makassar adalah $\pm 51 \mathrm{Km}$. Adapun luas wilayah Kabupaten Pangkep adalah 1.112,29 $\mathrm{Km}^{2}$ dengan batas-batas administrasi sebagai berikut:
a. Sebelah utara berbatasan dengan Kabupaten Barru
b. Sebelah selatan berbatasan dengan Kabupaten Maros 
c. Sebelah timur berbatasan dengan Kabupaten Bone dan Kabupaten Maros

d. Sebelah barat berbatasan dengan pulau Kalimantan, pulau Jawa dan Madura, pulau-pulau Nusa Tenggara dan pulau Bali. (Badan Pusat Statistik, 1999)

Kabupaten Pangkep pada tahun 1999 hanya terdiri dari sembilan kecamatan yaitu enam kecamatan daratan (Pangkajene, Balocci, Bungoro, Labakkang, Ma'rang, Segeri Mandalle) dan tiga kecamatan kepulauan (Liukang Tangaya, Liukang Kalmas, dan Liukang Tupabbiring) Sementara pada tahun 2016 Kabupaten Pangkep telah berkembang menjadi tiga belas kecamatan, yang terdiri dari sembilan kecamatan daratan (Tondong Tallasa, Minasatene, Segeri, Mandalle, Pangkajene, Balocci, Bungoro, Labakkang, dan Ma'rang), dan empat kecamatan kepulauan (Liukang Tupabbiring Utara, Liukang Tupabbiring, Liukang Kalmas, Liukang Tangaya). (Badan Pusat Statistik, 1999) \& (Badan Pusat Statistik, 2017)

\section{Penduduk}

Sumber utama data kependudukan adalah sensus penduduk yang dilaksanakan setiap sepuluh tahun sekali. Sensus penduduk telah dilaksanakan sebanyak enam kali sejak Indonesia merdeka, yaitu tahun 1961, 1971, 1980, 1990, 2000, dan 2010. (Badan Pusat Statistik, 2017)

Jumlah penduduk Kabupaten Pangkep pada tahun 1999 sebanyak 269.678 jiwa, tujuh belas tahun berselang yakni pada tahun 2016 jumlah tersebut meningkat menjadi 326.700 jiwa. Secara keseluruhan penduduk wanita pada tahun 1999 sedikit lebih banyak dibandingkan dengan penduduk laki-laki yakni 141.514 jiwa penduduk wanita dan 128.164 jiwa penduduk laki-laki. Begitupun pada tahun 2016 jumlah penduduk wanita masih lebih banyak dibandingkan laki-laki. Jumlah penduduk wanita adalah 168.724 jiwa dan penduduk laki-laki 157.976 jiwa. Sementara itu, kepadatan penduduk pada tahun 1999 adalah sebesar 242 jiwa/ $\mathrm{Km}^{2}$ sedangkan pada tahun 2016 rata-rata sebesar 294 jiwa/Km². (Badan Pusat Statistik, 1999) \& (Badan Pusat Statistik, 2017)

Adapun persebaran penduduk Kabupaten Pangkep yang berstatus Eksodus Timor Timur terdapat di sepuluh kecamatan dari total tigabelas kecamatan yang ada. Sepuluh kecamatan tersebut yakni Labakkang $156 \mathrm{KK}$, Pangkajene 42 KK, Segeri 27 KK, Ma'rang 20 KK, Bungoro $12 \mathrm{KK}$, Balocci $12 \mathrm{KK}$, Minasatene $11 \mathrm{KK}$, Tondong Tallasa 2 KK, Mandalle 2 KK, dan Liukang Tupabbiring 1 KK. (Komite Nasional Korban Politik Timor Timur (KOKPIT) Kabupaten Pangkep, 2015)

Kabupaten Pangkep pada umumnya dihuni oleh Suku Bugis dan Makassar. Selain itu juga terdapat suku Mandar yang menghuni wilayah kepulauan, suku Toraja dan Jawa yang merupakan penduduk pendatang serta beberapa suku lainnya namun dalam jumlah yang sedikit, tersebar di wilayah Kabupaten Pangkep. Masyarakat Kabupaten Pangkep pada umumnya menggunakan Bahasa Bugis dan Makassar dalam kesehariannya, selain bahasa Indonesia. Sedangkan masyarakat yang berada di Kecamatan Liukang Tangaya dan Kalukuang Masalima umumnya menggunakan bahasa Mandar dan Makassar. (Dinas Kependudukan dan Catatan Sipil, 2017).

\section{Pembahasan}

Timor Timur pada tahun 1999 genap berusia 23 tahun sebagai bagian dari Indonesia. Terhitung sejak ditanda tanganinya UU No. 7 tahun 1976 yang menandai resminya daerah tersebut menjadi provinsi ke-27 dari Republik Indonesia. (Hadi \& dkk, 2007). Perjalanan Timor Timur sebagai provinsi termuda di Indonesia kala itu berakhir setelah keluarnya hasil Jajak Pendapat yang menunjukkan bahwa, mayoritas warga Timor Timur lebih memilih untuk 
merdeka dibandingkan berintegrasi dengan Indonesia.

Selama menjadi bagian dari NKRI, daerah ini telah menarik masuknya banyak pendatang dari berbagai daerah di Indonesia. Termasuk diantaranya adalah Kabupaten Pangkep. Namun setelah diadakannya jajak Pendapat yang berakhir dengan kerusuhan, menyebabkan para pendatang tak terkecuali orang-orang Pangkep memilih untuk kembali ke kampung halamannya.

\section{Keberangkatan dari Timor Timur}

Lepasnya Timor Timur melalui pemungutan suara yang dimenangkan oleh mereka yang menginginkan kemerdekaan ternyata diikuti oleh sebuah kerusuhan berdarah yang besar disertai mengalirnya penduduk untuk menyelamatkan diri ke Timor Barat. Mungkin inilah peristiwa migrasi terpaksa (Forced Migration) yang pernah terjadi secara besar-besaran di Indonesia. Forced Migration rupanya menjadi sebuah gejala baru akibat terjadinya konflik berdarah di berbagai tempat di Indonesia: di Kalimantan Barat, Maluku, Kalimantan Tengah, Sulawesi Tengah, Aceh, Papua, dan tentu saja Timor Timur. (Tirtosudarmo, 2007).

Pada paragraf pertama diatas, tersaji analisa seorang ahli demografi Indonesia yang bernama Riwanto Tirtosudarmo, dalam memandang gelombang pengungsian secara besar-besaran dari Timor Timur. Dapat dilihat bahwa pada kutipan tersebut menggunakan istilah migrasi terpaksa (Forced Migration), yang merupakan salah satu teori migrasi yang dikemukakan oleh seorang ahli bernama Robert Norris pada tahun 1972. Pada penelitian ini untuk menjelaskan fenomena keluarnya penduduk dari Timor Timur menuju ke Kabupaten Pangkep, baik mereka yang berstatus sebagai pendatang, maupun penduduk asli Timor Timur akan menggunakan teori Robert Norris tersebut.

Teori-teori mengenai migrasi telah banyak dikemukakan oleh beberapa ahli, sebelum Robert Norris, telah ada seorang ahli bernama Everett Lee. Pada tahun 1970, Lee mengeluarkan hasil analisanya mengenai faktor-faktor yang menyebabkan seseorang berpindah dari satu tempat ke tempat yang lain.

Adapun menurut Everett Lee faktorfaktor yang mempengaruhi orang untuk bermigrasi dapat dibedakan menjadi empat yaitu; faktor-faktor yang berhubungan dengan tempat asal migran (origin), faktorfaktor yang berhubungan dengan tempat tujuan migran (destination), rintanganrintangan yang menghambat dan faktorfaktor Pribadi (Lembaga Demografi Fakultas Ekonomi Universitas Indonesia, 2004)

Teori Robert Norris pada 1972 melengkapi teori Everett Lee yaitu adanya migrasi kembali, kesempatan antara dan migrasi paksaan. Hal tersebut karena teori Everett Lee mengabaikan fungsi daerah antara dan tidak menjelaskan hubungan antara migran dengan daerah asal (Septiani, 2015). Teori Norris dapat dilihat pada diagram dibawah ini.

Gambar 1. Diagram Faktor-faktor Determinan Mobilitas Penduduk menurut Robert E. Norris

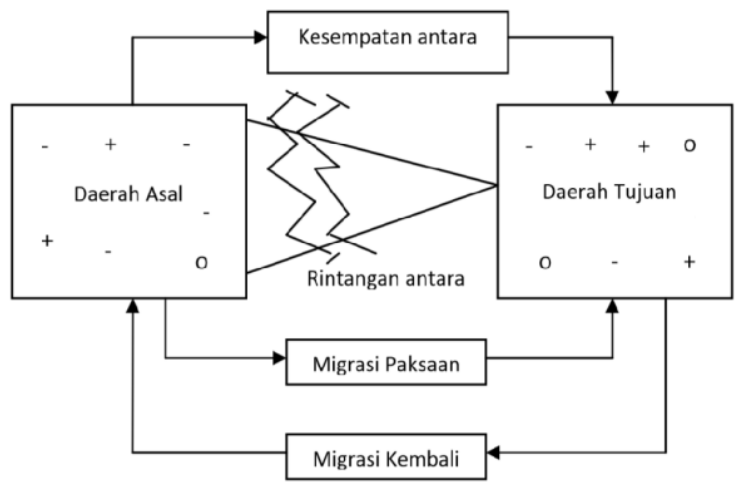

(Sumber: Annisa Fitri Septiani. Tingkat Keinginan Penduduk Untuk Berpindah Di Daerah Rentan Bahaya Longsor Desa Soko Kecamatan Miri Kabupaten Sragen, (Online: http://etd.repository.ugm.ac.id/downloadfile/79 578/potongan/S1-2015-

254303_introduction1.pdf), hlm. 20. Diakses 26 Februari 2018. ).

Faktor Daerah Asal (Origin) adalah faktor pendorong terjadinya migrasi. Pada 
umumnya faktor-faktor pendorong tersebut adalah sebagai berikut:

a. Makin berkurangnya sumber-sumber alam, menurunnya permintaan atas barang-barang tertentu yang bahan bakunya semakin susah diperoleh seperti hasil tambang, kayu atau bahan dari pertanian.

b. Menyempitnya lapangan pekerjaaan di tempat asal (misalnya di pedesaan) akibat masuknya teknologi yang menggunakan mesin-mesin (capital intensive).

c. Adanya tekanan-tekanan atau diskriminasi politik, agama, suku di daerah asal.

d. Tidak cocok lagi dengan adat/budaya/kepercayaan di tempat asal

e. Alasan pekerjaan atau perkawinan yang menyebabkan tidak bisa mengembangkan karir pribadi.

f. Bencana alam baik banjir, kebakaran, gempa bumi, musim kemarau panjang atau adanya wabah penyakit (Lembaga Demografi Fakultas Ekonomi Universitas Indonesia, 2004).

Faktor Daerah Tujuan (Destination) adalah faktor penarik terjadinya migrasi. Suatu daerah menjadi menarik sebagai tempat tujuan karena adanya faktor-faktor penarik dari daerah tersebut yang dinilai mampu memperbaiki keberlangsungan hidup. Berikut ini adalah beberapa faktor penarik yang pada umumnya menyebabkan terjadinya migrasi.

a. Adanya rasa superior di tempat yang baru atau kesempatan untuk memasuki lapangan pekerjaan yang cocok

b. Kesempatan mendapatkan pendapatan yang lebih baik

c. Kesempatan mendapatkan pendidikan yang lebih tinggi

d. Keadaan lingkungan dan keadaan hidup yang menyenangkan misalnya iklim, perumahan, sekolah dan fasilitas-fasilitas kemasyarakatan lainnya e. Tarikan dari orang yang diharapkan sebagai tempat berlindung

f. Adanya aktivitas-aktivitas di kota besar, tempat-tempat hiburan, pusat kebudayaan sebagai daya tarik bagi orang-orang dan desa atau kota kecil. (Lembaga Demografi Fakultas Ekonomi Universitas Indonesia, 2004). Faktor Rintangan Antara (Barriers) adalah faktor penghalang bagi para calon migran. Faktor ini bukanlah faktor utama yang menyebabkan seseorang memutuskan untuk berpindah atau tidak dari satu daerah ke daerah lain. Beberapa contoh penghalang adalah faktor geografis seperti jarak antara daerah asal dengan daerah tujuan.

Kesempatan Antara (Intervening Opportunities), atau yang juga dikenal dengan istilah daerah antara merupakan tempat di antara daerah asal dengan daerah tujuan, dimana migran telah mendapatkan kebutuhan yang sudah dapat dipenuhi. (Septiani, 2015)

Migrasi Terpaksa (Forced Migration) adalah kepindahan penduduk secara terpaksa karena mereka tidak mempunyai pilihan yang lebih baik selain mencari tempat baru untuk melangsungkan kehidupan. Kondisi yang memaksa sehingga menyebabkan terjadinya migrasi terpaksa pada umumnya terkait dengan kondisi fisik dan ekonomi. Pada kasus Timor Timor migrasi terpaksa terjadi karena adanya kerusuhan yang terjadi pasca Jajak Pendapat.

Migrasi Kembali (Return Migration) adalah peristiwa kembalinya para migran dari daerah tujuan ke daerah asal mereka. Hal ini bisa disebabkan karena tidak sesuainya antara harapan dengan kenyataan di daerah tujuan. Maupun tidak diterimanya para pendatang oleh para penduduk asli serta beberapa faktor lainnya yang mengharuskan para migran kembali ke daerah asal mereka.

Berdasarkan Teori Robert Norris maka peristiwa berpindahnya penduduk secara besar-besaran meninggalkan Timor 
Timur pada tahun 1999 dapat dibagi dalam dua kategori. Kategori pertama adalah Eksodus yang terdiri dari mereka para pendatang yang berasal dari beberapa daerah di Indonesia, dimana Kabupaten Pangkep adalah salah satunya. Eksodus kategori ini pada umumnya memilih untuk kembali ke kampung halaman mereka pada saat atau pasca terjadinya kerusuhan setelah pengumuman hasil Jajak Pendapat tahun 1999. Peristiwa kembalinya para pendatang ke daerah asal mereka termasuk kedalam jenis Migrasi Kembali (Return Migration).

Sedangkan Eksodus kategori kedua adalah mereka para penduduk asli Timor Timur yang secara terpaksa meninggalkan tanah kelahirannya untuk mengungsi ke wilayah Indonesia karena pertimbangan keamanan. Eksodus kategori kedua sebagian besar berada di wilayah Nusa Tenggara Timur seperti Timor Barat, Kupang, Kefamanu, dan Belu. Peristiwa berpindahnya penduduk asli Timor Timur menuju ke wilayah Indonesia karena terjadinya kerusuhan di daerah asal mereka termasuk kedalam jenis Migrasi Terpaksa (Forced Migration).

Eksodus kategori dua juga dapat dibedakan lagi menjadi dua. Kelompok pertama adalah mereka yang masih ingin kembali ke Timor Timur setelah situasi dan kondisi keamanan kembali kondusif. Mereka ini adalah orang Timor Timur yang mendukung kelompok pro-kemerdekaan. Kelompok kedua adalah mereka para pengungsi yang lebih memilih menetap di wilayah Negara Kesatuan Republik Indonesia sejak tahun 1999 hingga saat ini. Karena pada dasarnya mereka adalah bagian dari pendukung kelompok prointegrasi.

Demikianlah dapat dilihat bahwa Eksodus Timur Timor dapat diklasifikasikan dalam dua kategori utama, Sederhananya dapat dilihat pada bagan berikut.
Gambar 2. Bagan Klasifikasi Eksodus

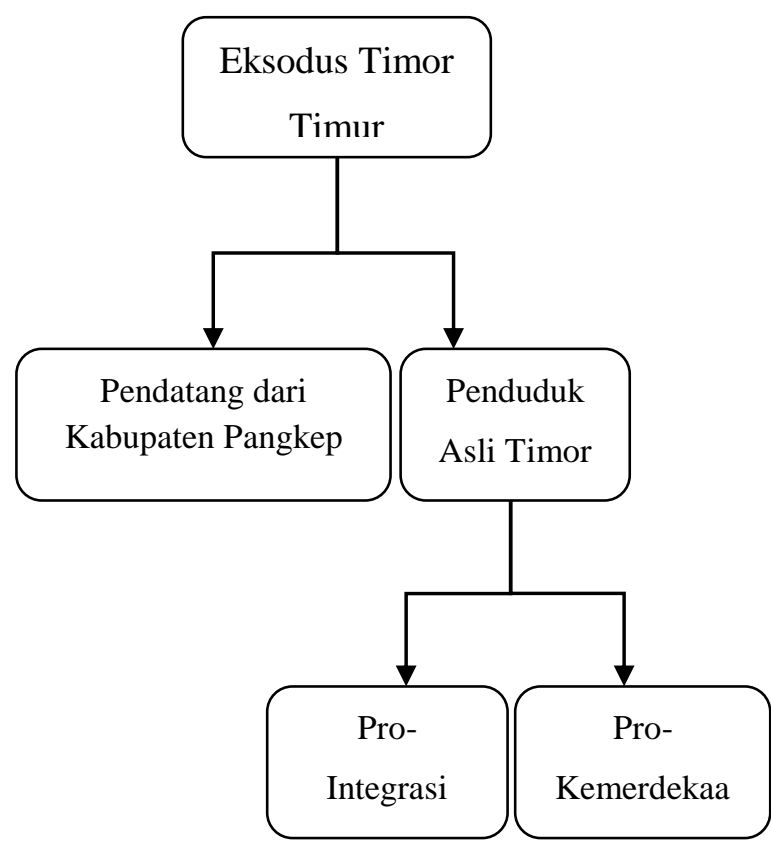

Return Migration

Forced Migration

Eksodus Timor Timur dari penduduk asli yang pro-kemerdekaan telah kembali ke tanah air mereka yang saat ini bernama Timor Leste. Sementara mereka yang masih setia kepada Indonesia (pro-integrasi) tetap bertahan di beberapa wilayah Indonesia, terutama di Provinsi Nusa Tenggara Timur. Nasib mereka masih terkatung-katung menanti realisasi janji berupa bantuan dari pemerintah, untuk melanjutkan kehidupan baru setelah harta benda mereka tinggalkan di Timor Timur.

Selain di Nusa Tenggara Timur, Eksodus dari kalangan penduduk asli Timor Timur juga dapat ditemukan dibeberapa daerah lainnya, seperti halnya 
di Kabupaten Pangkep. Eksodus dari kategori dua yang berada di luar provinsi Nusa Tenggara Timur pada umumnya disebabkan karena mereka mengikuti daerah asal suami atau istri mereka. Hal ini sebagaimana yang diungkapkan oleh seorang narasumber bernama Anwar Sadat, berikut ini.

"Sebelum Jajak Pendapat itu, kita ada perintah departemen dari pusat, itu menghimbau kepada seluruh PNS, TNI, Polri yang berkeluarga kawin silang itu untuk segera mengevakuasi keluarganya. Haaa... disitu. Jadi saya kebetulan saya punya istri orang Pangkep. Saya pernah tugas sementara enam bulan di Kanwil Makassar baru keluar SK penempatan di Pangkep. Tapi selama saya dari Timtim penitipannya adalah di Pangkep. Waktu itu ditanya sesuai dengan domisili keluarga yang di Pangkep.” (Sadat, 2018)

Anwar Sadat bersama dengan istri dan seorang anaknya meninggalkan Timor Timur berselang sehari pasca Jajak Pendapat dilaksanakan, yakni pada 1 September 1999. Berdasarkan penuturan beliau, adanya larangan dari milisi untuk meninggalkan Timor Timur bagi mereka yang keturunan asli telah membuat situasi menjadi mencekam kala itu. Sehingga menyulitkan para Eksodus kategori dua untuk menyelamatkan diri. Pada waktu itu untuk mengelabui para milisi, beliau dan keluarganya berangkat dari Ermera menuju pelabuhan di Kota Dili menggunakan ambulans, dengan suara sirine yang tetap berbunyi seolah mobil tersebut sedang memuat orang meninggal. Hanya dengan cara ini, keluarga beliau bisa diselamatkan karena seluruh akses transportasi menuju Kota telah di blokade oleh para milisi. Keberangkatan beliau sekeluarga menuju Ke Kabupaten Pangkep menggunakan transportasi jenis kapal laut. Pada waktu itu Anwar Sadat mendapatkan bantuan uang sebesar Rp1.000.000 dari Departemen Perindustrian dan Perdagangan karena berstatus sebagai PNS pada instansi tersebut. Dana tersebut diberikan untuk membiayai perjalanan menuju daerah tujuan mengungsi.

Eksodus dari kategori pertama, yakni para pendatang yang berasal dari beberapa daerah di Indonesia termasuk Kabupaten Pangkep. Menuturkan pengalaman dengan cerita yang tidak jauh berbeda dengan Anwar Sadat. Keberangkatan mereka dari Timor Timur juga menggunakan kapal laut, namun bedanya ada yang menggunakan biaya sendiri. Adapula yang menggunakan kapal gratis bantuan dari pemerintah Republik Indonesia, sebagaimana penuturan beberapa narasumber berikut ini.

"Saya dulu pulang tidak pake sendal, tidak kudapatmi toh. Pakaianku ku bungkus sarung karena tas-tas sudah napake semua ibu (baca: istri) pergi pulang duluan. Kan tidak ada persiapan. Pulang dadakan, karena orang sudah bakar-bakar rumah. Jadi napanggilma tentara pulang. Waktu itu Ibu pulang pakai biaya sendiri waktu bulan 11 tapi saya waktu pulang bulan 12 gratis, pake kapal pemerintah.” (Sanusi, 2018)

"Tidak adami kapal Indonesia kesana. Kapal terakhirmi, Pelni toh saya naiki kesini, yang dibelakangnya itu lewat Kupang mami orang. kalau saya masih Pelni Dili-Makassar yang terakhir, kapal terakhir.Pakai biaya sendiri waktu kita pulang, kalau dibelakangnya kan pemerintahmi yang anu, dari Kupang kesini.” (Muhris, 2018)

Penuturan kedua narasumber tersebut memberikan gambaran kepada kita bahwa proses kepulangan dari Timor Timur menuju ke Kabupaten Pangkep pada umumnya menggunakan kapal laut. Baik 
dengan biaya sendiri maupun yang mendapatkan bantuan dari pemerintah.

Perjalanan menuju ke pelabuhan oleh masing-masing narasumber meskipun dengan cara yang berbeda-beda, namun ada satu hal yang pasti sama, yaitu suasana mencekam. Jika Anwar Sadat sebelumnya menggunakan ambulans, maka dua narasumber yang disebutkan terakhir, yakni H. Sanusi dan Muhris memiliki cerita yang berbeda.

H. Sanusi sedikit lebih beruntung karena dijemput langsung oleh TNI di rumahnya menggunakan mobil militer sehingga perjalanan menuju ke pelabuhan cenderung lebih aman karena adanya perlindungan dari aparat keamanan. Apalagi jarak antara rumah narasumber dengan pelabuhan Dili tidak begitu jauh, karena ketika berada di Timor Timur, narasumber yang satu ini memang berdomisili di Kota Dili.

Cerita berbeda dikemukakan oleh Muhris yang ketika di Timor Timur tinggal di sebuah daerah bernama Lospalos, yang merupakan bagian dari Kabupaten Lautem. Keberangkatannya menuju pelabuhan Dili diwarnai ketegangan karena tidak adanya kendaraan umum yang berani beroperasi pada saat kerusuhan terjadi. Transportasi lumpuh karena blokade para milisi. Beruntung pada waktu itu, Muhris bertemu dengan keluarganya yang beristri orang Timor. Dari situlah Muhris meminta bantuan untuk diantar menuju ke Kota Dili. Biaya perjalanan yang biasanya hanya Rp25.000 menggunakan angkutan umum dari Lautem menuju ke Kota Dili menjadi dua kali lipat pada saat terjadi kerusuhan.

"Tujuh kalika waktu itu dihadang di jalan baru lolos ke pelabuhan. Pasukannya dulu Eurico dulu disitu masuk, karena nalarang orang Timor keluar toh. Jangan katanya masuk saja memilih baru keluar lagi. Kalau ada orang-orang hitang itu, langsung dia sikat disitu, brrr dedeh. Itu." (Muhris, 2018)
Aksi penghadangan yang dialami oleh Muhris berdasarkan penuturannya terjadi sampai tujuh kali sebelum akhirnya Ia sampai di pelabuhan Dili. Dirinya berhasil lolos karena adanya bantuan dari istri salah seorang keluarganya yang merupakan orang asli Timor Timur.

Titik keberangkatan kapal yang mengangkut Eksodus Timor Timur terdapat di dua tempat. Ada yang berangkat langsung dari pelabuhan Dili menuju pelabuhan Makassar, untuk selanjutnya melanjutkan perjalanan darat menuju Kabupaten Pangkep. Adapula yang meninggalkan Timor Timur menyeberang perbatasan ke Provinsi Nusa Tenggara Timur melalui jalur darat menuju pelabuhan di Kota Kupang. Dari sana kapal berangkat menuju pelabuhan Makassar, dan perjalanan dilanjutkan dengan transportasi darat menuju ke Kabupaten Pangkep.

Pada akhir tahun 2002, pihak berwenang Indonesia mencabut status "pengungsi" orang-orang Timor-Leste di Indonesia. Pada 2006, sekitar 60.000 orang masih tinggal di kamp-kamp "pengungsi" di Indonesia, menunggu pemindahan di desadesa permukiman kembali; banyak dari mereka adalah keluarga milisi dan terlalu takut untuk pulang ke Timor Leste. (Klinken, 2014).

Secara tidak sengaja mereka telah memilih menjadi orang Indonesia meskipun kebanyakan masih menganggap diri orang Timor-Leste. Mereka menolak dimukimkan kembali di tempat-tempat yang jauh, mau tinggal di pulau Timor karena dekat dengan kampung halaman. Banyak keluarga-keluarga pro-integrasi, khususnya anggota-anggota Apodeti yang telah hidup nyaman di masa kekuasaan Indonesia, membeli rumah dan mendirikan usaha di Indonesia, terutama di Timor Barat. Sekitar 60.000 orang Timor-Leste lainnya tetap bekerja dalam pemerintahan Indonesia atau dalam dinas-dinas keamanan, pekerjaan yang mereka jalankan 
pada waktu terjadinya referendum. (Klinken, 2014).

Kedatangan Eksodus Timor Timur ke Kabupaten Pangkep pasca Jajak Pendapat dilaksanakan telah memberikan gambaran kepada kita bagaimana bentuk Return Migration (migrasi kembali) dan Forced Migration (migrasi terpaksa) terjadi. Orangorang Pangkep yang memutuskan untuk kembali ke kampung halaman akibat kerusuhan yang berkepanjangan di Timor Timur adalah contoh migrasi kembali. Sementara kedatangan penduduk asli Timor Timur di Kabupaten Pangkep akibat terjadinya kerusuhan pasca Jajak Pendapat adalah contoh migrasi terpaksa.

\section{2. "Warisan" Untuk Timor Timur}

Kedatangan para pendatang telah memberikan warna tersendiri bagi Timor Timur terutama dalam dinamika kependudukannya. Berbagai macam suku bangsa dari berbagai daerah di Indonesia turut ambil bagian dalam hari-hari bersejarah Timor Timur, orang BugisMakassar yang berasal dari Kabupaten Pangkep adalah dua diantaranya.

Perhatian pemerintah pusat yang begitu tinggi pada Timor Timur telah menarik bagi para pendatang yang mengharapkan taraf perekonomian yang lebih baik. Sehingga tidak mengherankan jika para pendatang di Timor Timur pada umumnya berorientasi ekonomi. Begitupun dengan pendatang dari Kabupaten Pangkep, yang memilih merantau ke Timor Timur untuk mencari pekerjaan guna memperbaiki perekonomian keluarga mereka.

Orang Pangkep yang datang di Timor Timur memilih untuk bekerja sebagai pedagang di pasar, mulai dari pedagang kecil-kecilan hingga bisa menjadi distributor. Berbagai jenis komoditi yang diperdagangkan seperti pakaian, sepatu, sembako, sayur-sayuran hingga ikan telah menjadi rutinitas keseharian mereka.

Distributor barang di pasar-pasar tradisional Timor Timur memperoleh barang dari luar, salah satu diantaranya adalah kota Surabaya. Barang-barang tersebut bahkan dijemput langsung oleh distributor untuk kemudian dipasarkan di Timor Timur.

Kisah sukses dari orang-orang Pangkep yang bekerja sebagai pedagang dituturkan oleh Hasan yang dahulu ketika masih di Timor Timur adalah seorang distributor. Dari hasil usahanya Ia mampu membeli tanah dan membangun rumah serta ruko.

Selain sebagai pedagang juga terdapat pendatang dari Pangkep yang berprofesi sebagai PNS sambil membuka usaha lain, seperti membuat rumah kontrakan dan membuka toko campuran. Sebagaimana yang diutarakan oleh Salma.

"Iye, orang tuaku dulu disana PNS. Setelah adami pendapatan yang ditabung belimi tanah baru dikasi bangun kontrakan, sama buat toko campuran.” (Salma, 2017)

Peluang usaha baru dilihat oleh para pendatang yang cermat mengamati keadaaan sekitar. Fakta bahwa Timor Timur telah menjadi daerah tujuan para pendatang dari berbagai daerah telah menginspirasi orang tua Salma terhadap sebuah peluang usaha baru yakni membangun kontrakan. Target pasarnya adalah mereka para pendatang yang baru tiba di Timor Timur ataupun pendatang lama yang belum memiliki tanah dan rumah sendiri.

Banyak diantara para pendatang dari Pangkep telah memiliki aset di Timor Timur, yang diperoleh dari hasil usaha mereka selama berada disana. Terhitung sejak awal kedatangan mereka pada era 1980-an hingga kepulangannya kembali ke Kabupaten Pangkep pada 1999. Seperti yang telah diuraikan diatas berdasarkan hasil wawancara dengan narasumber, dapat diketahui bahwa setidaknya aset-aset yang dimiliki oleh para eksodus yakni berupa rumah, tanah, ruko, dan kontrakan.

Narasumber menjelaskan bahwa sebenarnya pasca Jajak Pendapat, dirinya 
masih berharap situasi Timor Timur akan kembali kondusif. Sehingga Ia bisa kembali melanjutkan usahanya disana. Namun kerusuhan masih terus berlanjut sehingga tidak memungkinkan baginya untuk tetap tinggal di Timor Timur. Maka jadilah Ia berangkat menuju ke kampung halaman dengan membawa barang-barang seadanya. Sementara aset-aset berupa rumah dan tanah ditinggalkan begitu saja.

“...Ada tempati itu rumahku sekarang di Timor Leste, tidak mau keluar. Seandainya mau keluar kembalika lagi kesana. Ada dua rumahku disana, Tanah juga ada disana, lengkap semua sertifikatnya, ada juga foto-fotonya saya punya. Itu dulu kukasi pak Hasan (ketua KOKPIT Sul-Sel) fotokopinya untuk dikirim ke Jakarta.” (Sanusi, 2018)

Serupa dengan penuturan H. Sanusi, narasumber lain yang bernama Muhris mengatakan bahwa tanah beserta kios tempat Ia membuka usaha ditinggalkan begitu saja. Ketika ditanya bagaimana status dan kondisi asetnya di Timor Timur beliau menuturkan sebagai berikut.

"Natempati orang Timor menjual sekarang. Karena ada info baru-baru saya dapat dari teman saya orang Enrekang toh, ada istrinya tinggal disana, orang Portu. Ada anaknya satu, dipanggil kesana jalan-jalan, dia dari kios. Singgah di rumah bermalam, dia bilang Ris saya singgah di kiosmu, behh ada orang Timor menjual disana. Hahaha...Nda berubahji katanya lokasi disana, tetap.” (Muhris, 2018).

Penuturan kedua narasumber tersebut menceritakan mengenai aset-aset berupa tanah dan rumah yang mereka miliki di Timor Timur saat ini telah diambil alih oleh orang Timor Timur tanpa adanya ganti rugi. Dikemudian hari, aset-aset inilah yang mereka perjuangkan untuk diganti secara layak oleh pihak berwenang, seperti halnya yang dijelaskan oleh Syamsul Hadi, dkk sebagai berikut.

Permasalahan turunan yang kemudian muncul setelah terjadinya peristiwa Eksodus besar-besaran pada tahun 1999 adalah perihal klaim kepemilikan aset milik penduduk sipil, perusahaan swasta dan BUMN Indonesia yang dahulu pernah eksis di Timor Leste. Total aset Indonesia yang berada di Timor Leste diperkirakan mencapai ratusan miliar rupiah yang terdiri dari aset bergerak dan tidak bergerak. Aset tidak bergerak yang ditinggalkan seperti gedung pemerintah, jalan dan jembatan, tanah, dan infrastruktur lainnya. Sedangkan aset bergerak terdiri dari hewan dan kendaraan. Registrasi aset-aset tersebut sampai saat ini masih terus dilakukan oleh Departemen Dalam Negeri. Sedangkan untuk aset-aset BUMN didaftar oleh Badan Perencanaan Pembangunan Nasional (Bappenas). (Hadi \& dkk, 2007)

Data yang tersaji pada sumber diatas, menunjukkan secara umum aset-aset Indonesia yang saat ini telah "diwariskan" untuk Timor Leste. Hingga saat ini proses negosiasi dengan pemerintah Timor Leste masih terus diupayakan untuk mendapatkan ganti rugi terhadap aset-aset tersebut. Disisi lain para Eksodus yang saat ini tinggal di Indonesia masih terus menanti dan sesekali mendesak pemerintah Indonesia untuk segera melakukan pembayaran ganti rugi terhadap aset-aset mereka di Timor Leste yang dahulu bernama Timor Timur. Mereka menganggap bahwa pemerintah Republik Indonesia harus bertanggung jawab terhadap aset-aset mereka yang ada disana, karena lepasnya provinsi ke-27 Indonesia tersebut menurut mereka karena kebijakan yang diambil oleh pemerintah.

Hasan salah seorang narasumber yang pada saat penelitian ini dilaksanakan masih menjabat sebagai ketua umum Komite Nasional Korban Politik Timor Timur (KOKPIT). Menjelaskan bahwa para warga Eksodus Timor Timur menanti aksi nyata dari pemerintah untuk bertanggung jawab 
atas aset-aset mereka di Timor Timur. Sampai saat ini mereka merasa seolah-olah pemerintah lepas tangan terhadap permasalahan itu. Padahal menurut mereka Jajak Pendapat terjadi bukan karena inisiatif sendiri dari penduduk Timor Timur, tetapi hal tersebut dimungkinkan karena kebijakan yang dikeluarkan oleh pemerintah. Sehingga pada akhirnya merekalah yang menjadi korban dari kebijakan tersebut. Atas dasar pertimbangan ini pula sehingga KOKPIT dibentuk pada tahun 2002 untuk mewadahi penduduk Indonesia yang berstatus Eksodus Timor Timur.

Syamsul Hadi, dkk. juga menguraikan bahwa Timor Leste tidak akan pernah lepas dari kedaulatan Indonesia kalau sekadar karena faktor kehebatan perjuangan Fretilin, desakan Australia, manuver diplomatik Portugal, ataupun keseriusan tekanan Amerika Serikat. Timor Leste berkesempatan lepas karena Habibie naik menjadi Presiden Republik Indonesia. Kebijakan pemerintah pusat Indonesia mengeluarkan opsi II (mengizinkan untuk merdeka bilamana menolak otonomi luas) bagi penduduk Timor Leste, dikeluarkan dimasa pemerintahannya. Kebijakan ini bersumber utama pada pertimbangan pribadi beliau atas kasus Timor Leste, dan merupakan titik balik dari kebijakan pemerintah pusat Indonesia terhadap kasus Timor Leste selama periode Integrasi. (Hadi \& dkk, 2007)

Tujuh belas tahun sudah sejak para Eksodus memutuskan untuk meninggalkan Timor Timur. Terhitung sejak 1999 hingga 2016 mereka telah tinggal di Kabupaten Pangkep namun permasalahan belum juga selesai. Tidak ada sumber sejarah pasti yang menyebutkan jumlah orang Pangkep di Timor Timur sebelum Jajak Pendapat tahun 1999, begitupun dengan jumlah orang Pangkep yang meninggalkan atau tetap memilih tinggal di Timor Timur pasca pengumuman hasil Jajak Pendapat yang berakhir dengan kerusuhan. Adapun sumber yang ada hanya menyebutkan mengenai jumlah mereka setelah berada di Kabupaten Pangkep. Sebagaimana data base yang diperoleh dari DPD Kabupaten Pangkep Komite Nasional Korban Politik Timor Timur yang memuat angka $286 \mathrm{KK}$ (285 KK berdomisili di Pangkep, sementera satu KK berdomisili di luar Kabupaten Pangkep tetapi tercatat sebagai penerima di daerah ini).

\section{E. Kesimpulan}

Situasi Timor Timur yang mencekam pasca Jajak Pendapat membuat banyak penduduknya memilih untuk meninggalkan daerah tersebut. Mereka yang memilih meninggalkan Timor Timur terdiri atas penduduk asli daerah tersebut maupun penduduk yang berstatus sebagai pendatang di Timor Timur. Oleh ahli demografi peristiwa keluarnya penduduk asli Timor Timur meninggalkan tanah kelahirannya termasuk dalam kategori migrasi terpaksa (Forced Migration) sementara para pendatang di Timor Timur yang memutuskan kembali ke kampung halamannya karena terjadinya kerusuhan termasuk dalam kategori migrasi kembali (Return Migration). Keberangkatan mereka meninggalkan Timor Timur pada umumnya menggunakan transportasi laut berupa kapal. Titik keberangkatan Eksodus Timor Timur ke Kabupaten Pangkep terdapat di dua tempat. Pertama, berangkat langsung dari Pelabuhan Dili menuju pelabuhan Makassar, untuk selanjutnya melanjutkan perjalanan darat menuju Kabupaten Pangkep. Kedua, adapula yang meninggalkan Timor Timur menyeberang perbatasan ke Provinsi Nusa Tenggara Timur melalui jalur darat menuju pelabuhan di Kota Kupang. Dari sana kapal berangkat menuju pelabuhan Makassar, dan perjalanan dilanjutkan dengan transportasi darat menuju ke Kabupaten Pangkep.

\section{DAFTAR PUSTAKA}


Abdullah, T. \& Adrian Lapian, (., 2012. Indonesia Dalam Arus Sejarah Jilid 8. Jakarta: Ichtiar Baru Van Hoeve.

Badan Pusat Statistik, 1999. Kabupaten Pangkep dalam Angka 1999. Pangkajene: BPS Kabupaten Pangkep.

Badan Pusat Statistik, 2017. Kabupaten Pangkep dalam Angka 2017. Pangkajene: BPS Kabupaten Pangkep.

Daliman, A., 2015. Metode Penelitian Sejarah. Yogyakarta: Ombak.

Departemen Pendidikan Nasional, 2003. Kamus Besar Bahasa Indonesia. III ed. Jakarta: Balai Pustaka.

Dinas Kependudukan dan Catatan Sipil, 2017. Profil Perkembangan Kependudukan Kabupaten Pangkajene dan Kepulauan 2016. Pangkajene: Dinas Kependudukan dan Catatan Sipil Kabupaten Pangkep.

Hadi, S. \& dkk, 2007. Disintegrasi Pasca Orde Baru, Negara Konflik Lokal dan Dinamika Internasional. Jakarta: Yayasan Obor Indonesia.

Hamid, A. R. \& Madjid, M. S., 2014. Pengantar Ilmu Sejarah. Yogyakarta: Ombak.

Hasan, 2017. Wawancara di Sudiang, Kota Makassar [Interview] (30 September 2017).

Klinken, H. V., 2014. Anak-anak Tim-Tim di Indonesia: Sebuah Cermin Masa Kelam. Jakarta: Kepustakaan Populer Gramedia.

Komite Nasional Korban Politik Timor Timur (KOKPIT) Kabupaten Pangkep, 2015. Dewan Pimpinan Daerah (DPD) Kabupaten Pangkep Komite Nasional Korban Politik Timor Timur (KOKPIT) Daftar Nama Anggota Calon Penerima Dana kompensasi Tahun 2015, Pangkajene: KOKPIT.

Lembaga Demografi Fakultas Ekonomi Universitas Indonesia, 2004. Dasar- dasar Demografi. Jakarta: Fakultas Ekonomi Universitas Indonesia.

Muhris, 2018. Wawancara di Pasar Sentral, Kabupaten Pangkep [Interview] (19 Februari 2018).

Sadat, A., 2018. Wawancara di Pangkajene, Kabupaten Pangkep [Interview] (21 Februari 2018).

Salma, 2017. Wawancara di Kantor Bupati Pangkep [Interview] (04 Oktober 2017).

Sanusi, H., 2018. Wawancara di Jalan Jeruk, Pangkajene. Kabupaten Pangkep [Interview] (19 Februari 2018).

Septiani, $\quad$ A. $\quad$ F., 2015. http://etd.repository.ugm.ac.id.

[Online]

Available at:

http://etd.repository.ugm.ac.id/downl oadfile/79578/potongan/S1-2015-

254303_introduction1.pdf

[Accessed 26 Februari 2018].

Sjamsuddin, H., 2016. Metodologi Sejarah. Yogyakarta: Ombak.

Tirtosudarmo, R., 1996. Demografi Politik Pembangunan Indonesia dari Riau Sampai Timor Timur. Jakarta: Pustaka Sinar Harapan.

Tirtosudarmo, R., 2007. Mencari Indonesia: Demografi Politik Pasca Soeharto. Jakarta: LIPI Press. 